\title{
NGHIÊN CỨU KẾT QUẢ ĐIỀU TRI XƠ GAN MẤT BÙ DO VIÊM GAN VIRUS B BẰNG PHƯƠNG PHÁP GHÉP TẾ BÀO GỐC TUỶ XƯƠNG
}

\author{
Đào Trường Giang**, Trần Việt Tú**, Mai Hồng Bàng*
}

\section{TÓM TẮT}

Mục tiêu: Đánh giá kết quả của ghép tế bào gốc tủy xương tự thân để điều trị xơ gan mất bù do viêm gan $B$. Đối tượng và phương pháp: 29 bệnh nhân xơ gan mất bù do virus viêm gan $B$ được điều trị ghép tế bào gốc tủy xương, từ tháng 6 năm 2016 đến tháng 8 năm 2019 và điều trị phác đồ chung cho bênh nhân xơ gan. Thu thập $300 \mathrm{ml}$ dịch tủy xương, sau đó lọc khối tế bào đơnn nhân, truyền vào qua qua động mạch gan. Các bệnh nhân được theo dõi trong 12 tháng và đánh giá kết quả dựa trên xét nghiệm cận lâm sàng và thang điểm Child- Pugh, MELD tại thời điểm 6 và 12 tháng. Kết quả: Nồng đô albumin máu có sư cải thiện có ý nghĩa thống kê ở tất cả các thời điểm 6,12 tháng. Điểm Child giảm có ý nghĩa thống kê với $\mathrm{p}<$ 0,05; điểm MELD giảm, tuy nhiên sự khác biệt không có ý nghĩa thống kê, với $p>0,05$. Sự khác biệt về tỷ lệ phân loại Child- Pugh ở thời điểm 6 tháng có ý nghĩa thống kê so với ban đâu, với $p<0,05$. Kết luận: ghép tế bào gốc ở bệnh nhân xơ gan bước đầu cải thiện chức năng gan, điểm Child- Pugh.

Từ khoá: xơ gan, ghép tế bào gốc, tuỷ xương, viêm gan virus $B$

\section{SUMMARY \\ STUDY THE TREATMENT RESULTS OF DECOMPENSATED CIRRHOSIS CAUSED BY HEPATITIS B VIRUS BY BONE MARROW STEM CELL TRANSPLANTATION}

Objectives: To evaluate the effectiveness of autologous bone marrow stem cell transplantation for the treatment of hepatitis B decompensated cirrhosis. Subjects and methods: 29 patients with hepatitis B virus decompensated cirrhosis received bone marrow stem cells transplantation treatment, from June 2016 to August 2019 and general regimen treatment for patients with cirrhosis. Collect $300 \mathrm{ml}$ of bone marrow fluid, then filter the mononuclear cell mass, then inject into the liver through hepatic artery. The patients were followed up for 12 months and efficacy was assessed based on laboratory tests and Child-Pugh and MELD scores at 6 and 12 months. Results: serum albumin levels had statistically significant improvement at all time points of 6,12 months. Child score decreased statistically with $\mathrm{p}<0.05$; MELD score decreased, but the difference was not statistically significant, with $\mathrm{p}>0.05$. The difference in the ChildPugh classification rate at 6 months was statistically

**Học viện Quân Y, Bộ Quốc Phòng *Bênh viến TWQE 108, Bô Quốc Phòng

Chịu trách nhiệm chính: Đào Trường Giang

Email: Giangle127@gmail.com

Ngày nhận bài: 21.6.2021

Ngày phản biên khoa hoc: 17.8.2021

Ngày duyệt bài: 25.8.2021 significant compared with baseline, with $p<0.05$. Conclusion: Stem cell transplantation in cirrhotic patients initially improves liver function, Child-Pugh score.

Key words: cirrhosis, stem cells transplantation, bone marrow, hepatitis $B$ virus

\section{I. ĐĂT VẤN ĐỀ}

Xơ gan là nguyên nhân gây tử vong phổ biến thứ 14 ở người trưởng thành trên toàn thế giới nhưng là nguyên nhân thứ tư ở Trung Âu; kết quả số ca tữ vong mỗi năm trên toàn thế giới là 1,03 triệu ca [1], ở châu Âu 170000 ca [2], và 33539 ca ở Hoa Kỳ [3]. Điều trị xơ gan giai đoạn mất bù chủ yếu là dự phòng và điều trị các biến chứng. Trên hết, phương pháp tối ưu nhất là ghép gan. Việc ghép gan hiện nay vẫn gặp nhiều khó khăn do thiếu hự gan lành, sự gia tăng số lượng bệnh nhân (BN) suy gan, và sự phụ thuộc nhiều vào trang thiết bị kỹ thuật của từng khu vực. Do đó, danh sách chờ đợi ghép gan ngày càng tăng, điều này đó đòi hỏi thực tiễn lâm sàng cần phải có chiến lược mới, bổ sung cho việc ghép gan, kéo dài sự sống cho BN.

Tủy xương là nơi cư trú của một hỗn hợp các tế bào gốc (TBG). Khả năng biệt hóa, tính mềm dẻo của chúng là cơ sở cho những liệu pháp điều trị bằng tế bào. Nhiều nhóm nghiên cứu đã tiến hành các thử nghiệm lâm sàng sử dụng tế bào tuỷ xương tự thân ở BN bệnh gan để điều trị xơ gan [4], [5]. Tuy nhiên liệu pháp điều trị tái sinh tế bào chưa thực sự trở thành phương thức điêu trị chính thống và trở thành biện pháp thường quy điều trị ở BN xơ gan.

Xuất phát từ thực tiễn trên chúng tôi tiến hành nghiên cứu để tài này nhằm mục tiêu: Đánh giá kết quả ghép tế bào gốc tuỷ xương tự thân điều trị xơ gan mất do viêm gan virus $B$.

\section{II. ĐỐI TƯỢNG VÀ PHƯƠNG PHÁP NGHIÊN CỨU}

2.1. Đối tượng nghiên cứu: $29 \mathrm{BN}$ xơ gan giai đoạn mất bù điều trị ghép TBG tủy xương và điều trị phác đồ chung cho BN xơ gan, tại Bệnh viện trung ương quân đội 108 từ tháng 6 năm 2016 đến tháng 6 năm 2019.

BN được chọn vào nghiên cứu khi thoả mãn tất cả các tiêu chí sau:

- Xơ gan do virus viêm gan $B$, có điểm Child Pugh $\leq 10$ có tuổi từ 35- 75

- BN đồng thuân tham gia nghiên cứu, có khả năng tự đọc hiểu đồng thuận khi tham gia 
nghiên cứu; Được hội đồng y đức thông qua.

- Bilirubin toàn phân < $85 \mu \mathrm{mol} / \mathrm{l}$.

- Dự kiến thời gian sống thêm trên 24 tuân.

BN bị loại ra khỏi nghiên cứu khi có một trong các tiêu chí sau đây:

- Nồng độ creatinin huyết thanh >150 $\mu \mathrm{mol} / \mathrm{l}$; INR $>2,5$

- Có ung thư gan hoặc ung thư cơ quan khác

- Xuất huyết tiêu, hoặc viêm phúc mạc vi khuẩn tự phát trong 1 tháng gân đây

- Có một trong các bệnh sau: hội chứng gan thận, hội chứng não gan, hội chứng gan phổi; rối loạn chuyển hóa nặng, rối loạn chức năng thận nghiêm trọng, các bệnh đường hô hấp, bệnh tim mạch và/hoặc các bệnh tâm thân, các bệnh nhiễm trùng hệ thống (bao gồm lao).

\subsection{Phương pháp nghiên cứu}

Thiết kế nghiên cứu: thử nghiệm lâm sàng có so sánh trước và sau điều trị.

\section{Các bước tiến hành:}

Bước 1. Tuyển chọn BN vào nghiên cứu: BN được tiến hành thăm khám lâm sàng, làm xét nghiệm (công thức máu, nhóm máu, đông máu toàn bộ, sinh hoá máu: chức năng gan, thận; enzym gan; nồng độ marker ung thư; siêu âm ổ bụng; nội soi dạ dày tá tràng; điện tim, X- quang tim phổi, chụp CT- scan gan mật 3 thì.

Bước 2. Thu gom khối TBG tuỷ xương: BN được chọc hút tuỷ xương khối lượng lớn từ $300 \mathrm{ml}$, sau đó lọc lấy TBG đơn nhân tuỷ xương.

Bước 3. Truyền khối TBG tuỷ xương: Khối TBG tuỷ xương được truyền chậm vào động mạch gan (phương pháp Seldinger).

Bước 4. Theo dõi và điêu trị: Tất cả các BN được điều trị thông thường phù hợp với giai đoạn xơ gan (thuốc kháng virus, bảo vệ tế bào gan) trong suốt quá trình theo dõi.

Chỉ tiêu nghiên cứu: đánh giá chức năng gan tại các thời điểm trước điều trị (TO); và sau điêu trị: 06 tháng (T6) và 12 tháng (T12); các thang điểm Child- Pugh, MELD.

Các biểu hiện lâm sàng liên quan đến gan sẽ được ghi nhận trong 12 tháng theo các tiêu chí sau: Cổ trướng mới xuất hiện biểu hiện lâm sàng rõ hoặc tăng nặng lên; Bệnh não gan; Chảy máu do tăng áp lực TMC; Viêm phúc mạc vi khuẩn tự phát; Hội chứng gan thận; HCC mới phát hiện và tử vong.

- Xử lý số liệu bằng phân mềm SPSS 25.0.

\section{KẾT QUẢ NGHIÊN CứU}

3.1. Đắc điểm của nhóm nghiên cứu và bàn luận. 29 BN xơ gan mất bù được điều trị khối TBG tuỷ xương tự thân được theo dõi trong
12 tháng với kết quả sau:

Bảng 1. Đặc điểm chung đôi tượng nghiên cứu

\begin{tabular}{|c|c|c|}
\hline Đắc điếm & \multicolumn{2}{|c|}{$\mathbf{n}=\mathbf{2 9}$} \\
\hline $\begin{array}{c}\text { Tuối trung bình } \\
\text { (X } \pm \text { SD) }\end{array}$ & \multicolumn{2}{|c|}{$57,97 \pm 8,18$} \\
\hline Tîên sử & Số lượng & Tỷ lệ \% \\
\hline XHTH do võ̃ TMTQ & 7 & 24,1 \\
\hline Bệnh não gan & 1 & 3,4 \\
\hline Cố trướng & 6 & 20,7 \\
\hline Vàng da & 4 & 13,8 \\
\hline Lâm sàng & & \\
\hline Cố trướng & 12 & 41,4 \\
\hline Lách to & 3 & 10,3 \\
\hline Tuần hoàn bàng hệ & 16 & 55,2 \\
\hline Giãn TMTQ & 22 & 75,9 \\
\hline Giãn TM phình vị & 1 & 3,4 \\
\hline
\end{tabular}

Tuổi trung bình của đối tượng nghiên cứu là $57,97 \pm 8,18$. Về tiền sử: Tỷ lệ BN có XHTH do võ TMTQ chiếm 24,1\%, bệnh não gan chiếm 3,4\%, cổ trướng 20,7\%. Biểu hiện lâm sàng: Tỷ lệ cổ trướng gặp 41,4\%; tuân hoàn bàng hệ $55,2 \%$, lách to $10,3 \%$. Giãn TMTQ chiếm 75,9\%; giãn TM phình vị chiếm 3,4\%.

Bảng 2: Sư thay đôi xét nghiệm sinh hoá máu qua thỡi gian theo dôi

\begin{tabular}{|c|c|c|c|}
\hline Chỉ tiêu & $\begin{array}{l}\text { Thời } \\
\text { điểm }\end{array}$ & $\begin{array}{c}\text { Nhóm ABMi } \\
(n=29)\end{array}$ & $\mathbf{p}$ \\
\hline \multirow{3}{*}{$\begin{array}{l}\text { Protein } \\
(\mathrm{g} / \mathrm{L})\end{array}$} & Ban đâu & $71,19 \pm 10,84$ & \\
\hline & 6 tháng & $71,31 \pm 8,07$ & p6-0 $=0,597$ \\
\hline & 12 tháng & $72,42 \pm 7,11$ & $p_{12-0}=0,139$ \\
\hline \multirow{3}{*}{$\begin{array}{l}\text { Albumin } \\
(\mathrm{g} / \mathrm{L})\end{array}$} & Ban đâu & $30,74 \pm 4,15$ & \\
\hline & 6 tháng & $32,94 \pm 4,57$ & $p_{6-0}=0,028$ \\
\hline & 12 tháng & $34,97 \pm 5,35$ & $p_{12-0}=0,002$ \\
\hline \multirow{3}{*}{$\begin{array}{l}\text { Bilirubin } \\
\text { tp } \\
(\mu \mathrm{mol} / \mathrm{L})\end{array}$} & Ban đâu & $40,98 \pm 18,23$ & \\
\hline & 6 tháng & $32,74 \pm 17,84$ & $\mathrm{p}_{6-0}=0,19$ \\
\hline & 12 tháng & $36,00 \pm 31,13$ & $p_{12-0}=0,555$ \\
\hline \multirow{3}{*}{$\begin{array}{l}\text { Prothrombin } \\
(\%)\end{array}$} & Ban đâu & $65,52 \pm 10,95$ & \\
\hline & 6 tháng & $70,82 \pm 12,65$ & $p_{6-0}=0,29$ \\
\hline & 12 tháng & $72,59 \pm 15,99$ & $p_{12-0}=0,136$ \\
\hline \multirow{2}{*}{ INR } & Ban đâu & $1,33 \pm 0,18$ & \\
\hline & 6 tháng & $1,29 \pm 0,15$ & $\mathrm{p}_{6-0}=0,252$ \\
\hline \multirow{3}{*}{$\begin{array}{l}\text { GOT } \\
(\mathrm{U} / \mathrm{L})\end{array}$} & Ban đâu & $73,17 \pm 35,60$ & \\
\hline & 6 tháng & $66,04 \pm 26,33$ & $\mathrm{p}_{6-0}=0,422$ \\
\hline & 12 tháng & $55,04 \pm 15,04$ & $p_{12-0}=0,031$ \\
\hline \multirow{3}{*}{$\begin{array}{l}\text { GPT } \\
(\mathrm{U} / \mathrm{L})\end{array}$} & Ban đâu & $46,79 \pm 24,24$ & \\
\hline & 6 tháng & $41,00 \pm 14,71$ & $\mathrm{p}_{6-0}=0,342$ \\
\hline & 12 tháng & $36,38 \pm 10,18$ & $p_{12-0}=0,050$ \\
\hline
\end{tabular}

Không có sự thay đổi có ý nghĩa thống kê về nồng độ protein, bilirubin, INR, prothrombin trong 12 tháng theo dõi tại các thời điểm 6 và 12 tháng, với $p>0,05$.

Tăng nồng độ albumin máu có sự cải thiện ở tất cả các thời điểm 6, 12 tháng, sự khác biệt có 
ý nghĩa thống kê với $p<0,05$.

Ơ thời điểm 6 tháng enzym gan GOT, GPT không có sự khác biệt so với trước điều trị, nhưng ở tháng 12 thì giảm rõ rêt với $p<0,05$.

Bảng 3: Sự thay đổi điểm Child - Pugh, MELD theo thời gian ở 2 nhóm

\begin{tabular}{|c|c|c|c|c|}
\hline \multirow{2}{*}{\multicolumn{2}{|c|}{$\begin{array}{c}\text { Chỉ số } \\
\text { Điếm Child - Pugh } \\
(X \pm \text { SD) }\end{array}$}} & \multicolumn{3}{|c|}{ Ban đâu 6 tháng } \\
\hline & & $\begin{array}{c}, 44 \pm \\
1,35\end{array}$ & $\begin{array}{c}6,38 \pm \\
1,21\end{array}$ & 02 \\
\hline $\begin{array}{c}\text { Điến } \\
\text { (X }\end{array}$ & $\begin{array}{l}\text { MELD } \\
\pm \text { SD) }\end{array}$ & $\begin{array}{c}13,94 \pm \\
2,93\end{array}$ & $\begin{array}{c}11,95 \pm \\
3,91\end{array}$ & 0,027 \\
\hline $\begin{array}{c}\text { Baveno } \\
\text { IV } \\
\text { số lượng } \\
(\%) \\
\end{array}$ & $\begin{array}{l}\text { Giai đoạn I } \\
\text { Giai đoạn II } \\
\text { Giai đoạn III } \\
\text { Giai đoạn IV }\end{array}$ & $\begin{array}{c}5(17,2) \\
2(6,9) \\
15(51,7) \\
7(24,1) \\
\end{array}$ & $\begin{array}{c}5(17,2) \\
1(3,4) \\
15(51,8) \\
8(27,6)\end{array}$ & 0,94 \\
\hline $\begin{array}{l}\text { Phân loại } \\
\text { Child- } \\
\text { Pugh } \\
\text { Số lượng } \\
\text { (\%) }\end{array}$ & $\begin{array}{l}\text { A } \\
B \\
C\end{array}$ & $\begin{array}{c}8 \\
(27,6 \%) \\
20 \\
(69,0 \%) \\
1(3,4 \%)\end{array}$ & $\begin{array}{c}17 \\
(58,6 \%) \\
12 \\
(41,4 \%) \\
0\end{array}$ & 0,044 \\
\hline
\end{tabular}

Khi so sánh sự thay đổi các thang điểm chức năng gan ở thời điểm trước và sau điều trị chúng tôi thấy tại thời điểm 6 tháng, điểm Child giảm có ý nghĩa thống kê với $p<0,05$; điểm MELD giảm, tuy nhiên sự khác biệt không có ý nghĩa thống kê, với $p>0,05$. Sự khác biệt về tỷ lệ phân loại Child- Pugh ở thời điểm 6 tháng khác biệt có ý nghĩa thống kê so với ban đầu, với $\mathrm{p}<$ 0,05 . Tuy nhiên, phân chia giai đoạn xớ gan theo Baveno IV khác biệt không có ý nghĩa thống kê ở thời điểm 6 tháng so với thời điểm ban đầu, với $\mathrm{p}>0,05$.

Bảng 4. Tỷ lệ xuất hiện các biến chứng trong thời gian 12 tháng

\begin{tabular}{|c|c|c|}
\hline \multirow{2}{*}{ Biến chứng } & \multicolumn{2}{|c|}{$(\mathbf{n = 2 9 )}$} \\
\cline { 2 - 3 } & $\begin{array}{c}\text { Trước } \\
\text { điêu trị }\end{array}$ & $\begin{array}{c}\text { Trong 12 } \\
\text { tháng }\end{array}$ \\
\hline XHTH do võ̃ TMTQ & $7(24,1 \%)$ & $4(13,8 \%)$ \\
\hline Bê̂nh não gan & $1(3,4 \%)$ & $1(3,4 \%)$ \\
\hline Viềm PM VKTP & 0 & 0 \\
\hline Cố trướng & $6(20,7 \%)$ & $20(69,0 \%)$ \\
\hline Vàng da & $4(13,8 \%)$ & $5(17,2 \%)$ \\
\hline
\end{tabular}

Biến chứng XHTH do võ TMTQ găp ở 4/29

$\mathrm{BN}$, biến chứng não gan gặp ở $1 / 29$ ca $(3,4 \%)$; Không gặp biến chứng VPMVKTP; Biến chứng cổ trướng gặp ở 20/29 BN, chiếm 69,0\%.

\section{BÀN LUẬN}

Xơ gan là một trong tiến triển của viêm gan $B$ mạn tính, theo Fattovich $G$ và cộng sự có từ 8$18 \% \mathrm{BN}$ viêm gan $\mathrm{B}$ mạn tính tiến triển thành $\mathrm{xo}$ gan sau 5 năm [6], vì vậy độ tuổi xơ gan liên quan đến nhiễm HBV thường là độ tuổi trung niên. Tuổi trung bình của nhóm nghiên cứu là $57,97 \pm 8,18$. Một số nghiên cứu trên thế giới về xơ gan cũng cho thấy tuổi trung bình của bệnh nhân xơ gan thường ở tuổi trung niên, trong đó độ tuổi 40 - 60 là chủ yếu.

Albumin và protein máu là một trong những chỉ số quan trọng phản ánh chức năng gan. Nghiên cứu chúng tôi cho thấy việc điều trị TBG tuỳ xương có sự cải thiện albumin máu ở thời điểm T6 và $T 12$ so với T0. Tuy chỉ là tăng nhe ở các thời điểm nhưng điều đó cũng cho thấy hiệu quả bước đầu của TBG tuỷ xương trong cải thiện chức năng gan. Nồng độ bilirubin toàn phẩn giảm ở T6, T12 so với T0, tuy nhiên sự khác biệt không có ý nghĩa thống kê với $p>0,05$. Nghiên cứu Terai và cs sử dụng ghép TBG tự thân từ tuỷ xương (autologous bone marrow cell infusion$\mathrm{ABMi}$ ) được ứng dụng từ năm 2003. Theo dõi sau 6 tháng [5], kết quả cho thấy có sự cải thiện rất đáng kể về nồng độ albumin huyết thanh, protein toàn phần, và Child-Pugh sau 6 tháng điều trị. Kết quả đó cũng tương tự khi theo dõi 9 BN sau 15 tháng. Kim và cs năm 2011 [7] cũng cho thấy TBG tuỷ xương cũng làm tăng nồng độ albumin huyết thanh, điểm Child- Pugh, và kết quả từ mảnh sinh thiết gan sau đó cho thây tác động tế bào HPC (hepatic progenitor cell) đóng vai trò nền tảng cho kết quả trên.

Khi so sánh sự thay đổi tỷ lệ xếp hạng điểm Child- Pugh ở nhóm nghiên cứu ở thời điểm trước và sau điều tri chúng tôi thấy tai thời điểm 6 tháng, điểm xếp hạng Child- Pugh giảm có ý nghĩa thống kê với $p<0,05$; điểm MELD giảm, tuy nhiên sự khác biệt giữa MELD tháng thứ 6 so với trước điều trị khổng có ý nghĩa thống kê, với $p>0,05$. Đồng thời khi so sánh xếp hạng ChildPugh theo A, B, C chúng tôi thây ở thời điểm 6 tháng, số lượng Child- Pugh $A$ của nhóm nghiên cứu tăng lên (từ 8 lên $17 \mathrm{ca}$ ), Child $\mathrm{B}$ giảm (từ 20 xuống $12 \mathrm{ca}$ ), và $1 \mathrm{ca}$ Child- Pugh $\mathrm{C}$ ở thời điểm ban đầu đã chuyển thành Child $B$, sự khác biệt có ý nghĩa thống kê với $p<0,05$. Terai và Cs 2006 [5] điều trị 9 BN xơ gan sử dụng tế bào tuỷ xương tự thân cho thấy có sự cải thiện điểm Child- Pugh vào tuân 24. Mohamadnejad và cs [9] điều trị BN xơ gan với tế bào gốc trung mô từ TBG tuỷ xương, cho thấy có sự cải thiện thang điểm MELD. Giảm điểm tiên lượng Child- Pugh là một dấu mốc đánh dấu tiên lượng tốt ở $B N$ xơ gan mất bù.

Bên cạnh đó, nghiên cứu của chúng tôi còn theo dõi sự xuất hiện các biến chứng của xơ gan: XHTH do võ TMTQ gặp ở 4/29, chiếm 13,8\%; Biến chứng não gan gặp 1/29 ca $(3,4 \%)$; Viêm phúc mạc vi khuẩn tự phát (VPMVKTP) gặp 0/29 ca (0\%); Cổ trướng gặp 20/29 ca $(69,0 \%)$. 
So với trước điều trị thì số lượng biến chứng XHTH do võ TMTQ đã giảm đáng kể; biến chứng cổ trướng và vàng da không giảm là do trước điều trị số lượng BN cổ trướng chiếm 12/29 ca hiện đang có cổ trướng, vàng da có $4 / 29 \mathrm{ca}$. Điều này có thể lý giải là do khi đã ở giai đoạn mất bù thì sự hiện diện của cổ trướng, vàng da khó có sự đảo ngược về giai đoạn trước đó. Biến chứng XHTH do võ TMTQ giảm hơn trước điều trị (so với tiền sử) có thể giải thích một phần là do việc tham gia vào nghiên cứu, $B N$ quan tâm đến điều trị hơn, chấp hành tốt hơn việc dùng thuốc giảm áp lực TMC và theo dõi nội soi chặt chẽ hơn.

\section{KẾT LUÂ̂N}

- Tuổi trung bình nhóm nghiên cứu là 57,97 $\pm 8,18$.

- Không có sự thay đổi có ý nghĩa thống kê về nồng độ protein, bilirubin, INR, prothrombin trong 12 tháng theo dõi tại các thời điểm 6 và 12 tháng, với $p>0,05$. Nồng độ albumin máu có sự cải thiện có ý nghĩa thống kê ở tất cả các thời điểm 6,12 tháng.

- Điểm Child giảm có ý nghĩa thống kê với $p$ < 0,05; điểm MELD giảm, tuy nhiên sự khác biệt không có ý nghĩa thống kê, với $p>0,05$. Sự khác biệt về tỷ lệ phân loại Child- Pugh ở thời điểm 6 tháng khác biệt có ý nghĩa thổng kê so với ban đầu, với $p<0,05$.

TÀI LIỆ THAM KHẢO

1. Lozano, R., et al., Global and regional mortality from 235 causes of death for 20 age groups in 1990 and 2010: a systematic analysis for the Global Burden of Disease Study 2010. Lancet (London, England), 2012. 380(9859): p. 2095-2128.

2. Blachier, M., et al., The burden of liver disease in Europe: a review of available epidemiological data. Journal of hepatology, 2013. 58(3): p. 593-608.

3. Hoyert, D.L. and J. Xu, Deaths: preliminary data for 2011. National vital statistics reports : from the Centers for Disease Control and Prevention, National Center for Health Statistics, National Vital Statistics System, 2012. 61(6): p. 1-51.

4. Gordon, M.Y., et al., Characterization and clinical application of human CD34+ stem/progenitor cell populations mobilized into the blood by granulocyte colony-stimulating factor. Stem Cells, 2006. 24(7): p. 1822-30.

5. Terai, S., et al., Improved liver function in patients with liver cirrhosis after autologous bone marrow cell infusion therapy. Stem Cells, 2006. 24(10): p. 2292-8.

6. Fattovich, G., F. Bortolotti, and F. Donato Natural history of chronic hepatitis B: special emphasis on disease progression and prognostic factors. Journal of hepatology, 2008. 48(2): p. 335-352.

7. Kim, J.K., et al., Autologous bone marrow infusion activates the progenitor cell compartment in patients with advanced liver cirrhosis. Cell Transplant, 2010. 19(10): p. 1237-46.

8. Saito, T., et al., Potential therapeutic application of intravenous autologous bone marrow infusion in patients with alcoholic liver cirrhosis. Stem Cells Dev, 2011. 20(9): p. 1503-10.

9. Mohamadnejad, M., et al., Phase 1 trial of autologous bone marrow mesenchymal stem cell transplantation in patients with decompensated liver cirrhosis. Arch Iran Med, 2007. 10(4): p. 459-66.

\section{SO SÁNH KẾT QUẢ ĐIỀU TRI CỦA LIỆ PHÁP TIÊM NộI KHỚP BẰNG ACID HYALURONIC REGENFLEX BIO - PLUS SO VỚI GO - ON TRONG ĐIỀU TRI THOÁI HÓA KHỚP GỐI NGUYÊN PHÁT}

\section{TÓM TẮT}

Thoái hóa khớp là bệnh lý thoái hóa khớp mạn tính có đặc điểm là đau khớp và hạn chế chức năng khớp tiến triển. Tiêm hyaluronic acid ( $\mathrm{HA})$ nội khớp, trong đó, tiêm nội khớp với chế phẩm Regenflex Bio-Plus (RBP) với 1 lần/1 đợt điều trị và Go - on với 3-5 lần/1 đợt điều trị là liệu pháp điêu trị đã được chứng minh

\footnotetext{
${ }^{1}$ Trường Đại học Y Hà Nội

${ }^{2}$ Bệnh viện Bạch Mai

Chịu trách nhiệm chính: Trần Thị Tô Châu

Email: tranthitochau72@yahoo.com.au

Ngày nhận bài: 22.6.2021

Ngày phản biện khoa học: 18.8.2021

Ngày duyệt bài: 24.8.2021
}

Trần Thị Thu Trang ${ }^{1}$, Trần Thị Tô Châu ${ }^{2}$

có tác dụng giảm đau và cải thiện chức năng vận động. Mục tiêu: So sánh kết quả điêu trị của liệu pháp tiêm nội khớp bằng acid hyaluronic Regenflex Bio-plus so với Go - on và các tác dụng không mong muốn của Regenflex Bio-plus trong điều trị thoái hóa khớp gối nguyên phát. Đối tượng và phương pháp nghiên cứu: Nghiên cứu thử nghiệm lâm sàng có đối chứng theo dõi trong 3 tháng trên 63 bệnh nhân thoái hóa khớp gối nguyên phát chia làm 2 nhóm: 37 bệnh nhân được tiêm RBP và 26 bệnh nhân được tiêm Goon, cả 2 nhóm được phối hợp thuốc CVKS và SYSADOA. Kết quả: Tại tháng thứ 2 và thứ 3 sau can thiệp, nhóm tiêm nội khớp RBP có mức độ cải thiện thang điểm VAS và WOMAC tốt hơn so với nhóm tiếm Go - on có ý nghĩa thống kê. Điểm VAS trung bình giảm từ 5,41 xuống 2,7 điểm, WOMAC trung bình giảm từ 30,92 xuống 12,13 ở nhóm RBP, trong khi đó 